811.163.41'342.8

https://doi.org/10.18485/sj.2018.23.1.8

МИЛОРАД П. ДЕШИТ

Универзитет у Београду

Филолошки факултет
Оригинални научни рад

Примљен: 04. 01. 2018.

Прихваћен: 29. 01. 2018.

\title{
СРПСКИ СТАНДАРДНИ АКЦЕНАТ И ПРЕФИКСАЦИЈА ИМЕНИЦА
}

О акценту префиксалних ријечи није много писано. Кад се о томе расправљало, говорило се само о акценту основног облика лексеме с префиксом, али није о акцентима осталих облика. У овом прилогу алкценти именица су подијељени у двије групе: лексички (обухватају двије лексеме: основну ријеч и префиксал) и морфолошки (акценти облика). Полазећи од лексичког акцента, примјери су разврстани у двије велике групе: у првој је лексички акценат на основи префиксала, а у другој је тај акценат на префиксу. С обзиром на степен промјена акцента, обје групе се састоје од три подгрупе: у једној нема промјене акцента ни у основној лексеми ни у префиксалу, у другој је промјена акцента само у основној лексеми, а у трећој долази до промјене акцента и у основној лексеми и у префиксалу.

Кључне ријечи: акценат, префиксација, лексички, морфолошки, префиксал, лексема, промјена акцента, проклитички, преклитички.

О акценту ријечи с префиксима писано је мало, више узгред. И кад је писано, разматран је само акценат основног облика лексеме с префиксом, а занемаривани су акценти облика у деклинацији и конјугацији и њихов однос према акценту основне ријечи. Да би излагање о овој сложеној материји било јасније и прецизније, најприје смо акценте подијелили у двије групе:

"milorad.desic@gmail.com 
у једној су лексички (Л), а у другој граматички, у ствари морфолошки (М) акценти. Лексички акценти се односе на двије лексеме: на основну ријеч (О) и на префиксал (П), који се састоји од префикса и основе префиксала (ОП). Морфолошки акценти укључују акценте облика О и П. Односи између акцената основне ријечи и префиксала, као и акценатски односи у границама ових двију лексема, исказују се акцентограмима, тј. групама акценатских знакова (укључујући и неакцентоване дужине) уз које иду бројеви слогова на којима се јављају акценти и гдје су болдом истакнути акцентовани слогови префикса. Акценат у П може бити једнак ономе у О (исти акценат на истоме мјесту), али може се наћи и на префиксу. Ово друго, преношење акцената на префикс, двојако је: у једном случају је проклитичко (са основе силазне интонације, слично преношењу акцената на проклитике), а у другом случају је преклитичко (са основе узлазне интонације, префиксално преношење акцената у ужем значењу ријечи).

Основу за подјелу на двије велике групе чини лексички акценат: он може бити на основи префиксала, а може и на префиксу.

\section{І. ЛЕКСИЧКИ АКЦЕНАТ НА ОСНОВИ ПРЕФИКСАЛА}

У овој групи постоје три подгрупе.

\section{1. Нема промјене акцента ни у основној лексеми ни у префиксалу}

Јављају се једносложни и двосложни префикси, домаћи и страни. На основи префиксала могу да стоје и а)узлазни и б)силазни акценти.

а) Парови са узлазним акцентима:

фило̀зоф - надрифило̀зоф, проду̀киија - хиперпроду̀киија (`2 - 4); структу́ра - инфраструкту́ра, култу́ра - монокулту́ра (' 2 - ' 4); симѐтрија - асимѐтрија, инфѐкиија - дезинфѐкиија, проду̀киија - копродукиија ('2 -'3); сезо́на - вансезо́на, култу́ра - супкулту́ра (' 2 -' 3); еконо̀мија - макроеконо̀мија, органйзам - микроорганѝзам, психологија - парапсихологија ('3 - `5);

про́стор - међупро́стор (' 1 - ' 3), књѝже̄внӣк - надрикњѝже̄внӣк ('1-2 ${ }^{-} 3$ -`3 $\left.{ }^{-}{ }^{-} 5\right)$, колонијализам - неоколонијалйзам ('5 - '7), модернйзам - постмодернйзам ('3 - '4), númāґье - потпи́та̄ње (' $\left.1^{-} 2-{ }^{-} 2^{-} 3\right)$, премије́ра - претпремије́ра (' 3 -' 4), офанзи́ва-противофанзи́ва ('3 - '5), осигура́ғье-реосигура́ње ('4-' 5), рѐвйзија - суперрѐвйзија ('1 ${ }^{-} 2$ - ' $\left.3^{-} 4\right)$.

Понекад се сусрећемо и са двоакценатским П (један акценат на основи, други на префиксу):

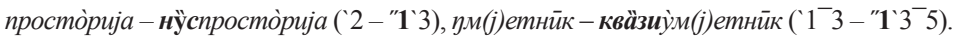


Ријетки су дублети у П: у једном је један члан двоакценатски, у другом одговара дублет у О:

револу́чија - контрареволу́ичја / кӧнтрареволу́ција (' 3 -’ 5/"1' 5); ха̀рмо̄нија/

Врло риједак је случај у којем према дублету у О стоји триплет у П (двапут акценат на основи, једном на префиксу):

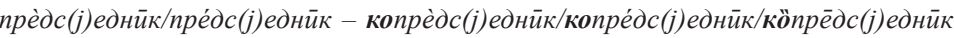
$\left(1^{-} 3 /^{\prime} 1^{-} 3-2^{-} 4 /^{\prime} 2^{-} 4 /^{\prime \prime} 1^{-} 2^{-} 4\right)$.

б) Кад се силазни акценти нађу на ОП, преузети из О, доспију на унутрашње слогове ријечи, што се коси са основним правилима српске акценатске норме. Међутим, овакве акценте требало би прихватити као стандардне, јер су већ били на почетку основне ријечи, а и сада су у почетном дијелу, одмах иза префикса. У ствари, овдје се, као и у претходним примјерима, огледа тежња да се сачува акценат $\mathrm{O}$.

Поред пара прӥвреда - ванпрӥвреда ("1 - "2) налазимо и друге, друкчије. Међу њима су, на примјер, парови са двоакценатским П (акценат на основи и на префиксу), неки пут дати у облику дублета којем одговара дублет у О:

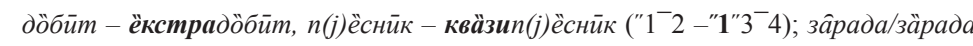
- нйззаิрада/нйззӓрада (^1/"1 - "1²/"1"2).

Префикси екстра- и квази- акцентовани су и због њиховог значења истицања, посебности.

У неким дублетима у П други члан не припада овој групи јер је акценат на префиксу или је узлазни на основи:

ӱслуга - противйслуга/прӧтивуслуга ("1 -"3/"1); на̂пад/на́nад - противнаิпад

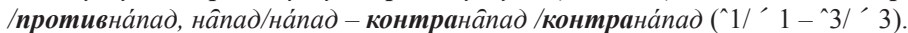

\section{2. Промјена акцента само у основној лексеми}

У грађи су се нашли једносложни и двосложни префикси страног поријекла. Акценатски односи у паровима су исти као у непрефиксалним ријечима у Даничићевим Српским акиентима. То потврђују примјери:

Л (лексички акценат): фа̀mиста - антифа̀mиста ('1 -’3).

M (морфолошки акценат): фа̀mиста, ген. мн. фӓшӣста̄-антифа̀mиста ('1,"1 ${ }^{-} 2^{-} 3$

-’3). (акценат као код ба̀тина-пријатѐљица);

Л: фа̀шиста- профа̀mиста ('1 -'2).

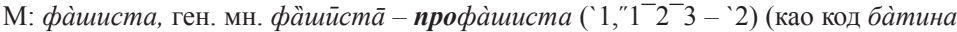
-бера̀чииа);

Л: ѝзбор-рейзбор ('1 -'2).

М: йзбор, ген. мн. ӥзборра - рейзбор ( $11^{\prime \prime} 1^{-} 2^{-} 3$ - `2) (као јѐзик - кукуेруз); акценат као у пару фа̀mиста - проффа̀mиста; 
Л: дра́ма/дрӓма-монодра́ма /мӧнодрама (' 1/"1 - '3/" 1).

M: дра́ма, потенцијални вок. драิмо/ дрӓма, ген. мн. драิма̄-монодра́ма/ мӧнодрама (' $1,{ }^{\wedge} 1 /{ }^{\prime \prime} 1,{ }^{-}{ }^{-} 2-{ }^{\prime} 3 /$ " 1$)$. Овој групи припада први члан дублета у О и у П, тј. пар дра́ма-монодра́ма (као ку́ма - апоте́ка).

\section{3. Промјена акцента и у основној лексеми и у префиксалу}

\section{1. Акценат не прелази на префикс}

У прикупљеном материјалу налази се највише именица са двосложним префиксима, а рјеђе са једносложним и тросложним. Сви су страног поријекла.

У основи префиксала акценат се мијења као у О, па се у неким примјерима силазни акценат нађе на унутрашњим слоговима П:

Л: ло́по̄в-архило́по̄в (' $\left.1{ }^{-} 2-{ }^{-} 3^{-} 4\right)$.

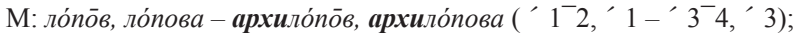

Л: крешенндо - декрешѐндо ('2 -’3). $\left.3^{-} 4\right)$

М: крешѐндо, ген. мн. креше́нда̄-декрешѐндо, ген. мн. декреше́нда̄ ('2,' $2^{-} 3$-`3,

Л: милио̀не̄p-мултимилиоेне̄р (' $\left.3^{-} 4-5^{-} 6\right)$.

М: милиоेне̄p, милионе́ра, вок. мйлионе̄ру -мултимилио̀не̄p, мултимилионе́ра, вок. мултимйлионеру (' $3^{-} 4,{ }^{\prime}, 4,{ }^{-} 4-{ }^{-} 5^{-} 6,{ }^{\prime}$ ' 6,"3-6);

Л: дрџсава - супердѐжава ('1 -’3). "3-4-5);

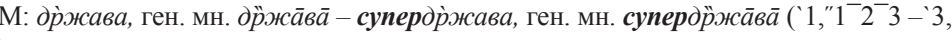

Л: дѐснииа -ултрадѐсница ('1 -`3).

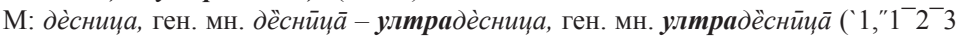
- '3,"3-4- 5). Овај пар је једнак пару држжава - супердр’жава.

Има потврда и за дублете у П. Један акценатски пар овако ћемо представити:

Л: сйла - суперсйла/су̀персила ("1 -"3/'1). $\left.3^{-} 4 /{ }^{\prime} 1\right)$

М: сйла, ген. мн. сиิла̄ - суперсйла, ген. мн. суперсиิла̄/ су̀nерсила ("1, 1, ${ }^{-} 2$-"3,

Овом пару припада само први члан дублета (суперсі̃ла). Силазни акценти се налазе у О и у П (у П на унутрашњим слоговима ријечи у Л и у М), у ствари они из О сачувани су у основи П.

У неким дублетима у П, акценту основе једног члана додаје се акценат на префиксу. И овдје се јавља, у оба члана дублета, силазни акценат у унутрашњости одређеног облика:

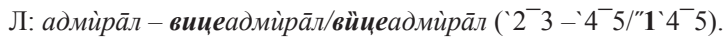

М: адмѝра̄л, адмира́ла, вок. ӓдмира̄ле - вицеадмѝра̄л, вицеадмира́ла, вок.

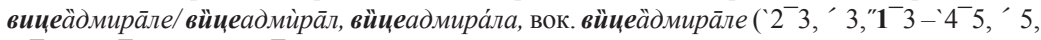
"3-5/"1`4-5,"1’ 5,"1"3-5). 
Исти акценат има и пар адмѝра̄л - контраадмѝра̄л/кӧнтраадмѝра̄л. Такође, једнаки су акценти у паровима етйлён - полиетѝлён и адмйра̄л - вицеадмйра̄л.

Ријетко се дешава да према дублету у О стоје два дублета у П. У једном дублету П налази се силазни акценат у унутрашњости одређеног облика, а акценту основе једног члана дублета додаје се акценат на префиксу (у функцији истицања):

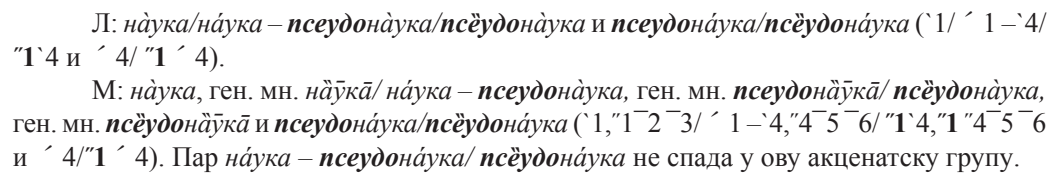

M: на̀ука, ген. мн. нӓӯка̄/ на́ука-псеудона̀ука, ген. мн. псеудонӓӯка̄/nсёудона̀ука, ген. мн. псёудонӓӯка̄ и псеудона́ука/псёудона́ука ('1,"1-2-3/' 1 - -4,"4-5 6/"1'4,"1"4-5 6 и ' 4/"1'4). Пар на́ука - псеудона́ука/ псёудона́ука не спада у ову акценатску групу.

У П сљедећег пара такође стоји силазни акценат у средини једног облика, а акценту основе додат је акценат на префиксу:

Л: иампѝо̄н-ёксшампѝо̄н ( $\left.2^{-} 3-" 1 ` 3-4\right)$.

М: иампѝо̄н, цампио́на, вок. шаимпио̄не - ёксшампѝо̄н, ёксшампио́на, вок.

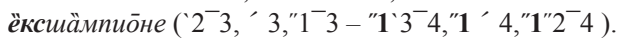

\section{2. Акценат прелази на префикс}

У анализираној грађи јављају се именице са једносложним (чешће) и двосложним префиксима, који су домаћег (чешће) и страног поријекла.

У једном облику П имамо проклитички однос према $\mathrm{O}$, тј. проклитичко преношење акцената са основе силазне интонације:

Л: пу̀ша̄ч-непу̀ша̄ч $\left(1^{-} 2-2^{-} 3\right)$.

М: пу̀ша̄ч, пуша́ча, вок. пӱша̄чу - непу̀ша̄ч, непуша́ча, вок. нёпуша̄чу ( $11^{-} 2,{ }^{\prime}, 2,{ }^{-} 2$ - '2-3,' 3,"1-3) (као непрефиксални пар ві́jнд́к-капе̌т $\check{E} н)$.

Вокативни пар: пи́māчy - нёnуша̄чy.

Слично се акценатски понашају и неки парови у којима је лексички акценат у П дублетни:

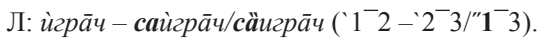

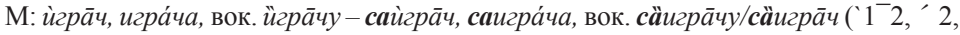
"1 ${ }^{-} 2-2^{-} 3,{ }^{\prime} 3,^{-} \mathbf{1}^{-} 3$ "1 $\left.^{-} 3\right)$.

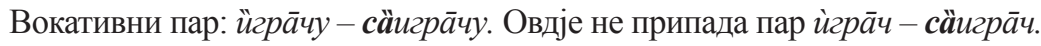

Акценат пара пѝло̄m - копѝло̄m/ кӧпило̄m једнак је акценту пара ѝгра̄ч - caѝгра̄ч/ сӓигра̄ч.

И морфолошки акценат може у П бити дублетни:

Л: вре́ме (ек.)-међувре́ме (' 1 -’’3).

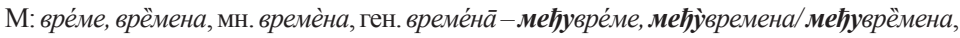

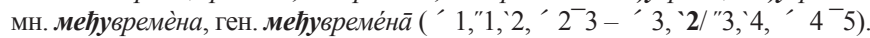


Проклитичко преношење акцената на други слог префикса овдје захвата једнинске облике: врёмена-међуेвремена, врёмену-међуेвремену, врёменом - међуेвременом. Облици са силазним акцентом у средини (међуврёмена и др.) не припадају овој групи.

Ијекавски лик има акценат као у екавском - разлика је само у основном, лексичком облику: вре́ме: вријѐме (' 1 :'2)-међувре́ме : међувријѐме (' 3 :'4).

\section{II. ЛЕКСИЧКИ АКЦЕНАТ НА ПРЕФИКСУ}

И у овој групи постоје три подгрупе.

\section{4. Нема промјене акцента ни у основној лексеми ни у префиксалу}

Забиљежили смо једносложне и двосложне префиксе, домаће и стране. Преношење акцента на префикс је проклитичко или преклитичко (преношење са основе узлазне интонације - префиксално у ужем значењу ријечи).

\section{1. Проклитичко преношење}

Најприје неколико једноставнијих примјера:

Л: фйлм -мйкрофилм ("1 -"1);

Л: рёктор - проेректор ("1 -’1) (код Даничића брӓтић - уेчитељ);

Л: пуิтнйк-са̀nутнйк ( $1^{-} 2-{ }^{-} \mathbf{1}^{-} 3$ ) (без дужине непосредно иза акцента).

У једном пару лексички акценти се налазе у проклитичком односу, али морфолошки акценти (у множинским облицима О и П) појављују се у дублетима чији само први члан припада овој групи:

Л: стӓв- прӧтивстав ("1 -"1).

М: стӓв, мн. стӓвови/ ста̀вови-прӧтивстав, мн. прӧтивставови/противста̀вови ("1, "1/ 1 -"1,"1/³) (ван ове групе су чланови дублета: ста̀вови и противста̀вови).

Лексички дублети могу да се јаве у П или у О и у П:

Л: бӓс - кӧнтрабас/ко̀нтрабас ("1 - "1/ 1) (у другом члану дублета узлазни акценат на првом слогу двосложног префикса; код Даничића цӓр - прӓунук(у̀читељ);

Л: коิнзул/кӧнзул - вйцеко̄нзул/ вйцеконзул ("1/"1 -"1-3/"1) (код Даничића добогш/ брӓтић - Дӱгобра̄ђић/Вӓсојевић).

Уочен је и примјер у којем се поред лексичког дублета у П налази и дублет једног облика О:

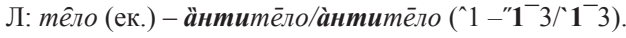

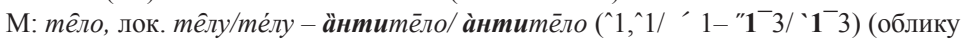
те́лу нема овдје мјеста; у другом члану лексичког дублета узлазни акценат на првом слогу двосложног префикса). 
Ијекавски лик акценатски се понаша слично екавском, са класичним замјенама гласа јата, нпр.: тијѐлу).

Л: тӥјело (ијек.) - ӓнтитијело/ а̀нтитијело ("1 -"1/21) (ван групе локативно

\section{2. Преклитичко преношење}

Акценат на префиксу може бити силазни, али и узлазни:

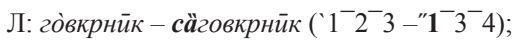

Л: си́нус - коेсинус (' 1 -"1) (код Даничића на́род - уेчитељ).

Риједак је примјер са дублетом у О и са два дублета у П, од којих је само први у овој групи (са силазним акцентом на префиксу):

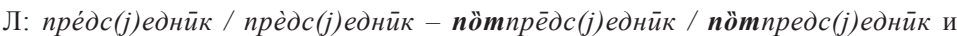
потпре́дс(j)еднйк / потпрѐдс(j)еднйк ( ${ }^{\prime} 1^{-} 3 /{ }^{\prime} 1^{-} 3-{ }^{-} 1^{-} 2^{-} 4 /{ }^{\prime \prime} 1^{-} 4$ и ' $\left.2^{-} 4 / 2^{-} 4\right)$.

\section{5. Промјена акцента само у основној лексеми}

Појављују се именице са једносложним (већином) и двосложним префиксима, домаћим и страним. Преношење акцента на префикс је проклитичко и преклитичко.

\section{1. Проклитичко преношење}

Најједноставнији примјери били би:

Л: краิљ - ёкскра̄sь (^1 -"1 $\left.{ }^{-} 2\right)$.

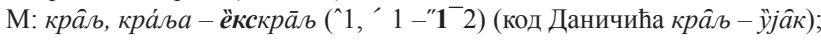

Л: краิљ-вйцекра̄љ (^1-"1-13).

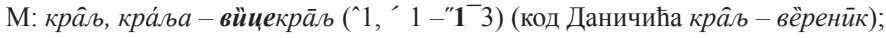

Л: рёд - нёре̄д (^1 -"1-2).

М: ре̂д, лок. ре́дy, мн. рёдови - нёрёд (^1,’'1,"1-"1-2);

Л: Хрйст - а̀нтихрист (безбожник) ("1 -’1).

М: Хрйст, Хрйста - àнтихрист ("1,’1 - ’1) (узлазни акценат на 1. слогу двосложног префикса).

У неким паровима налазе се дублети и триплети у множинским облицима:

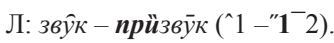

М: звуิк, лок. зви́ку, мн. звуิиии/зв́кови, ген. зви́ко̄ва̄/звуко́ва̄, дат. звуิичима/зву́ковима/

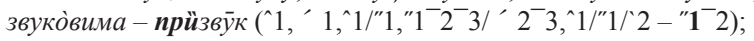

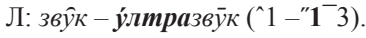

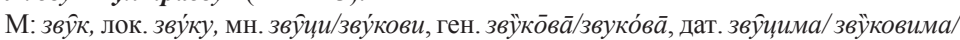

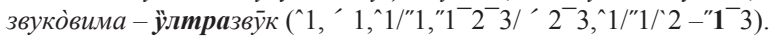


Понекад се јави лексички дублет у П, са силазним или узлазним акцентом на префиксу:

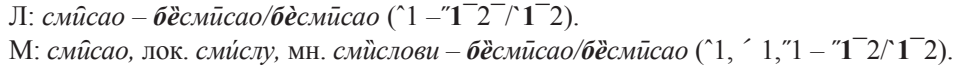

\section{2. Проклитичко преношење}

Најчешћи примјери у грађи су они у којима се краткоузлазни акценат налази на првом слогу $\mathrm{O}$, а краткосилазни на једносложном префиксу. Тако имамо:

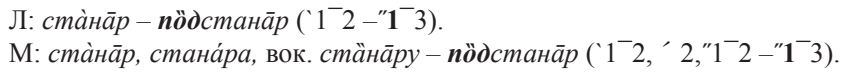

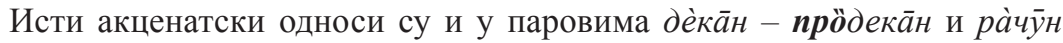
- прёдрачу্ун (неуобичајен вокатив у О).

Слично је и у примјеру:

Л: уेнук-прӓунук ('1-"1).

М: у̀нук, ген. мн. у́нуॅка̄-прӓунук ('1,"1 $\left.1^{-} 2^{-} 3-" 1\right)$.

Среће се и понеки примјер са краткоузлазним акцентом на непочетном слогу O:

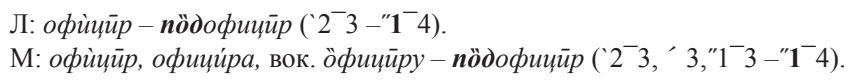

\section{6. Промјена акцента и у основној лексеми и у префиксалу}

Ова промјена акцента, према грађи, односи се на именице са домаћим префиксима, једносложним и ријетко двосложним. Лексички акценти обично се налазе у проклитичком односу, а морфолошки акценти много чешће стоје на префиксу него на основи П.

\section{1. Морфолошки акценти на префиксу}

Једнакост у акценту може да постоји између парова са различитим префиксима. Поћи ћемо од аљедећег пара:

$$
\text { Л: срёћа-нѐсрећа ("1 -'1). }
$$

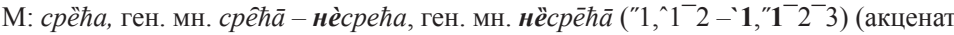
као код непрефиксалних именица књйга - ба̀тина).

Овом акценатском типу припада и пар грӱпа - по̀dгрупа.

У исти тип дјелимично су укључени и парови са лексичким дублетним акцентима П: слӧга - нѐслога/нёслога и бӓба - пра̀баба/прӓбаба. Наиме, са паром срёћа - нѐсрећа слажу се комбинације са првим чланом дублета: слӧга 
- нѐсллога и бӓба - пра̀баба. Довољан доказ је промјена акцента у првом пару:

Л: слӧга - нѐслога/нёслога ("1 -'1/"1).

М: слӧга, ген. мн. слорга̄ - нѐслога, ген. мн. нёсло̄га̄/ нёслога ("1, $1^{-} 2-{ }^{-} 1,1^{-} 2^{-} 3$ / "1).

Навешћемо и неколико других акценатских типова:

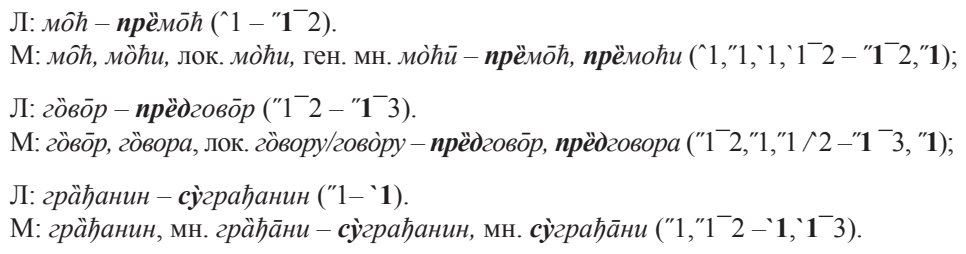

Риједак је примјер са двоструким префиксом и двоструким акцентом, силазним на првом и узлазним на другом слогу:

Л: бӓба - прӓпра̀баба ("1 -"122).

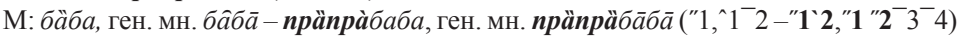
(силазни акценат у средини ријечи).

\section{2. Морфолошки акценти на основи префиксала}

Забиљежен је један пар, и то са морфолошким дублетним акцентима у О и у П:

Л: спрӓm - мёђууспрат ("1-"1).

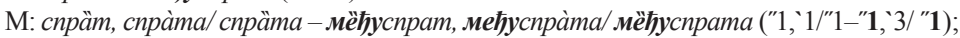
основном пару припада комбинација спра̀та-међуспра̀та.

6.3. Посебан случај представљају два пара у којима морфолошки акценти префиксала у једнинским облицима стоје на префиксу, а у множинским на основи:

Л: чäc-npèmчас ("1-'1).

М: ча̋c, ча̀ca, мн. ча̀сови - прѐmчас, мн. претча̀сови ("1,'1 - '1,'2);

Л: вре́ме (ек.) - нёврёме (' 1 - "1, $\left.{ }^{-} 2\right)$.

М: вре́ме, врёмена, мн. време́на, ген. време́н $\bar{a}-$ нёврёме, нёвремена, мн. невремѐна, ген. невреме́н $\bar{a}\left({ }^{\prime} 1,,^{\prime} 1,2^{\prime}, 2^{-} 3-{ }^{-} 1^{-} 2, " 1,3,{ }^{\prime} 3^{-} 4\right)$ (једини примјер у којем се лексички акценти налазе у преклитичком односу).

У ијекавском лику акценат је као у екавском - разлика је само у основном, лексичком облику:

$$
\text { вре́ме : вријѐме (' 1:'2)-нёврёме : нёвријеме ("1-2: "1). }
$$

7. Закључујући излагање, истаћи ћемо неколико најважнијих чињеница. Прије свега, у анализираној грађи налазе се именице обично са једносложним и двосложним префиксима, ријетко тросложним. Они су домаћи или су страног поријекла. 
Ради лакше анализе, акценти су подијељени у двије групе: лексички (обухватају двије лексеме: основну ријеч и префиксал, састављен од префикса и основе префиксала) и морфолошки (акценти облика основне ријечи и префиксала). Односи између акцената основне ријечи и префиксала, као и акценатски односи у границама ових двију лексема, исказују се акцентограмима, тј. групама акценатских знакова уз које иду бројеви слогова на којима се налазе акценти и неакцентоване дужине. Поред тога, полазећи од лексичког акцента, примјери су разврстани у двије велике групе: у првој је лексички акценат на основи префиксала, а у другој је тај акценат на префиксу. Обје групе дијеле се даље на три подгрупе: у једној нема промјене акцента ни у основној лексеми ни у префиксалу, у другој је промјена акцента само у основној лексеми, а у трећој долази до промјене акцента и у основној лексеми и у префиксалу.

Што се тиче односа између лексичких и морфолошких акцената у префиксалу, може се рећи да се они поклапају кад се акценат не мијења у парадигми. Међутим, кад се акценат мијења, може да дође до одређених разлика у неким облицима или чак у цијелој парадигми. Тако се у групи гдје је лексички акценат на основи префиксала неки пут појави морфолошки акценат на префиксу, а у групи у којој је лексички акценат на префиксу нађе се понекад морфолошки акценат на основи префиксала. А кад је ријеч о преношењу акцената на префикс, рећи ћемо да је оно двојако: проклитичко (са основе силазне интонације) и преклитичко (са основе узлазне интонације - префиксално у ужем смислу ријечи).

За акценат префиксала карактеристично је и сљедеће: неки префиксали су двоакценатски (један акценат на основи, други на префиксу), а неки се појављују у облику акценатских дублета, чак и триплета. Осим тога, у неким лексемама и у неким облицима префиксала налазимо силазне акценте ван почетног слога, које треба прихватити као стандардне.

Најзад, треба поменути још двије чињенице: прво, у истом акценатском типу могу се наћи именице са различитим префиксима; друго, префиксалне именице често имају исти акценат на истоме мјесту као и непрефиксалне.

\section{ЛИТЕРАТУРА}

Даничић 1925: Ђуро Даничић, Српски акиенти, Београд - Земун: Српска краљевска академија.

Дешић 1992: Милорад Дешић, Српски акиенат с лакоћом, Београд: Завод за уџбенике и наставна средства. 
Клајн 2002: Иван Клајн, Творба речи у савременом српском језику 1, Београд: Завод за уџбенике и наставна средства: Институт за српски језик САНУ; Нови Сад: Матица српска.

Николић ред. 2007: Речник српскога језика, редактор и уредник Мирослав Николић, Нови Сад: Матица српска.

Стевановић 1964: М. Стевановић, Савремени српскохрватски језик I, Београд: Научно дело.

\section{STANDARD SERBIAN STRESS AND PREFIXATION OF NOUNS}

\section{Summary}

There has not been much writing on the stress in prefixed words, and even when writing on the subject, only the stress of the prefixed lexeme in nominative case was discussed, not the stress of lexemes in other cases. In this paper, stress in nouns is divided into two groups: lexical (comprising the two lexemes: the base word and prefixed one) and morphological (stress in other cases). Starting with lexical stress, examples are classified into two large groups: the first group includes examples of lexical stress on the stem of the prefixed word, while the second one includes lexical stress on the prefix. Depending on the type of changes in stress, both groups are further divided into three subgroups: the first subgroup includes examples where no changes in stress occur in either base or prefixed lexeme, the second includes the ones where change in stress occurs only in the base word, whereas the third subgroup comprises examples where changes in stress occur in both base and prefixed lexeme. The author analyzes the correlation between lexical and morphological stress in a prefixed word, pointing out that the movement of stress to the prefix is two-way: proclitic (moving from stem with falling stress) and prefixal in narrower sense (moving from stem with rising stress).

Key words: stress, prefixation, lexical, morphological, prefixed word, lexeme, change in stress, proclitic, prefixal movement. 